Aim of the study: To evaluate the impact of different types of physical activity on life satisfaction, acceptance of illness and adaptation to breast cancer among women after treatment. Material and methods: 36 women after treatment of breast cancer with mean age of 59 years $( \pm 10.2)$ were assessed with the satisfaction of life scale, acceptance of illness scale, and Mental Adjustment to Cancer Scale. Physical activity within the group was evaluated.

Results: Those women $(81 \%$ of the group) who participated in Breast Cancer Survivors' Club meetings had higher scores on the AIS $(p=0.01)$, which means better acceptance of illness and disability. They also had high awareness of the importance of physical activity for recovery after treatment of breast cancer. $94 \%$ of the group confirmed that regular physical training was necessary. $82 \%$ of them found that they spent more time on training than before the operation. Within the most active subgroup (more than 5 types of activity) higher scores of the fighting spirit item in the Mini-MAC scale $(p=0.019)$ were observed. Tourist trips (fighting spirit $p<0.01$, positive attitude: $p=0.055$, constructive style: $p<0.01)$ and dance (SWLS: $p<0.05$, AIS: $p<0.05$ ) had a significant impact on quality of life. Conclusions: Women after treatment of breast cancer had high awareness of the impact of physical activity on recovery. The study subgroup of women who were most active had a better strategy of fighting spirit. Among many types of physical activity, tourist trips and dance were the most important for quality of life. Physical activity seemed to be profitable also for the subgroup outside the Breast Cancer Survivors' Club.

Key words: breast cancer, physical activity, AIS, SWLS, Mini-MAC.

\section{Physical activity, life satisfaction and adjustment to illness in women after treatment of breast cancer}

\author{
Iwona Malicka', Joanna Szczepańska-Gieracha', Ewelina Jankowska ${ }^{1}$, \\ Marek Woźniewski ${ }^{1}$, Joanna Rymaszewska ${ }^{1,2}$
}

${ }^{1}$ Chair of Physiotherapy in Conservative and Operative Medicine, Faculty of Physiotherapy, University of Physical Education in Wroclaw, Poland 2Laboratory of Consultation Psychiatry and Behavioural Medicine Chair and Clinic of Psychiatry, Medical University of Wroclaw, Poland

\section{Introduction}

Oncological treatment is a complex and long-term process which is usually associated with stress because of specific features of the neoplastic disease, therapeutic methods and side effects of therapy [1-4]. Surgery, chemoand radiotherapy often result in functional and emotional disorders, as well as changes in behaviour, lifestyle and self-perception [5]. The patient's attitude towards the disease, in turn, has an impact on the quality of life and, as research shows, may determine the final effects of treatment [6].

Benefits of rehabilitation exercise introduced during oncology treatment are currently regarded as unquestionable. The main goal of kinesitherapy in this period is to restore the full range of motion in the shoulder joint on the side of the operated limb and to prevent lymphoedema. Recent years, however, have seen increased attention to the importance of physical activity undertaken by women after completing treatment [7-9]. Systematic physical exercise improves the patient's physical performance and general body efficiency, as well as preventing excessive weight gain, enhancing the immune system and even staving off the ageing process [9].

Physical activity also has a favourable effect on the emotional condition of patients suffering from malignancies. It helps reduce anxiety and depression accompanying the disease, which translates into improved quality of life and better daily functioning. Indirect benefits of physical activity in patients with chronic life-threatening disease include better compliance and a more positive attitude to long-term therapy and the recovery period [10, 11]. However, it remains an open question whether different types of recreational physical activity have the same influence on the quality of life of women after breast cancer treatment.

The aim of the study was to assess life satisfaction and psychological adjustment to the cancer experience depending on the type of physical activity undertaken by patients.

\section{Material and methods}

The study was carried out in a group of 36 women post-breast cancer treatment. The mean age of the subjects was 59 years $( \pm 10.2)$. Radical mastectomy was performed in $85 \%$ of the study patients, while breast-conserving therapy (BCT) was selected as a treatment option in 15\% of the subjects. In addition, $85 \%$ of the patients underwent adjuvant treatment. Radiotherapy was introduced in 61\%, chemotherapy in 58\% and hormone therapy in $55 \%$ of the women enrolled in the study. The mean time from the completion of treatment was 6 years $( \pm 5.1)$. During that period, cancer recurred in 


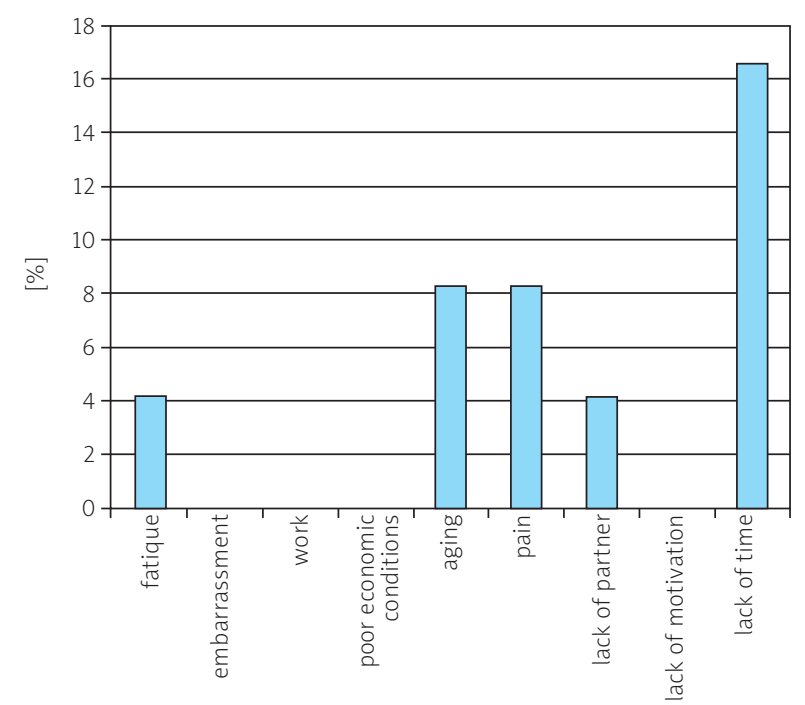

Fig. 1. Causes of lack of physical activity among study group

three of the patients who then underwent additional surgical treatment within the other breast.

The study was performed on the basis of diagnostic survey methods, using the questionnaire technique. The main research tool was a patient questionnaire comprising five main sections:

1. Basic personal and medical data.

2. Section concerning physical activity undertaken by the women.

3. Satisfaction with Life Scale (SWLS) developed by Diener et al. $[12,13]$. The scale assesses the subjective feeling of life satisfaction by comparing patients' life situation against their predefined standards. If the overall score is positive, the feeling of satisfaction is assumed. The scale was translated and adjusted to the Polish setting by Z. Jurczyński [5].

4. Acceptance of Illness Scale (AIS). The scale is used for measuring the degree of acceptance of the disease. The greater the acceptance of the disease, the better the adjustment and lower the mental discomfort experienced by the patient. The scale was translated and adjusted to the Polish setting by Z. Jurczyński [5].

5. Mental Adjustment to Cancer Scale (MAC) developed by Watson et al., in an abbreviated version (Mini-MAC) [14]. The scale assesses the following strategies: constructive style of coping with the disease (CS) consisting of the following attitudes: fighting spirit (FS) and positive orientation to the illness (PO); and destructive style of addressing the disease, comprising anxious preoccupation (AP) and helplessness-hopelessness $(\mathrm{HH})$. The scale was translated and adjusted to the Polish setting by Z. Jurczyński [5]. Statistical analysis was performed using the Statistica package (version 8). Kolmogorov-Smirnov test was also used to determine whether the empirical distribution deviated from the hypothetical normal distribution. Due to the nature of the material collected in the study, statistical analysis was performed using non-parametric tests and the MannWhitney $U$ test was carried out.

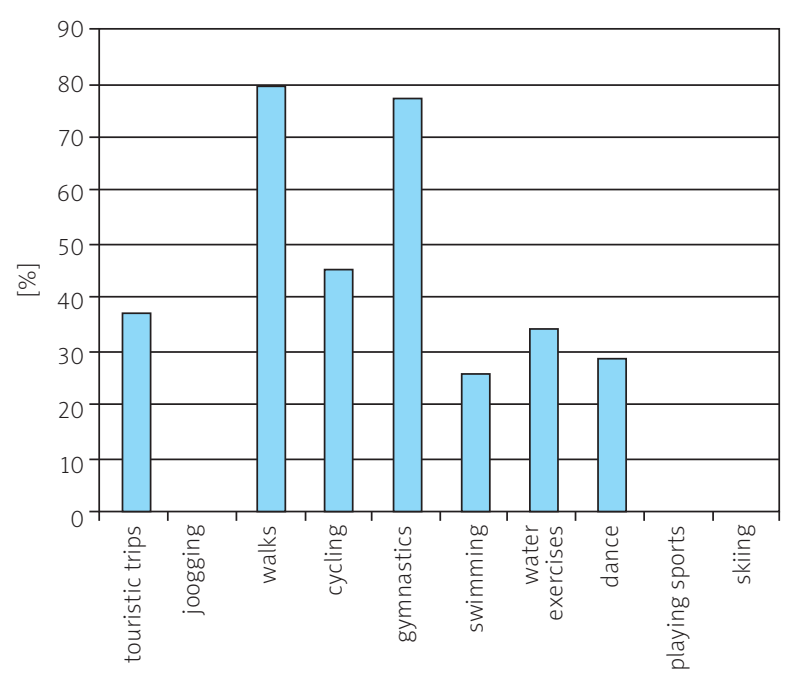

Fig. 2. Types of physical activity

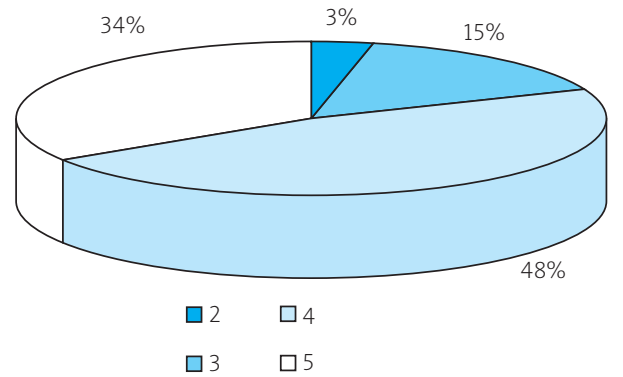

Fig. 3. Intensity of physical activity based on 1-7 scale (1 - very light effort, 7 - very intense effort)

\section{Results}

The results showed that $81 \%$ of the study women participated in meetings held at the "Amazons" Breast Cancer Survivors' Club ("Amazons Club"). However, out of the seven women who did not attend Amazons Club meetings, four did not have such a possibility because there was no local Amazons Club branch in the vicinity. The conclusion is, therefore, that out of all study women who had a chance of attending meetings of the support group, an impressive 91\% used the opportunity. Higher AIS scores were recorded among Amazons Club members (vs. non-members), which shows their better adjustment to the disease and disability $(p=0.01)$.

The majority of women participating in the study (94\%) stated that regular physical activity after oncology treatment is necessary. At the same time, however, every fifth polled woman admitted she failed to practise physical activity on a regular basis, quoting inadequate time (17\%), pain (8\%) and old age (8\%) as the main reasons for not taking up physical exercise (Fig. 1). Nevertheless, no less than $82 \%$ of patients believed they still devoted more time to physical recreation activities after the surgery than before the operation. The most popular activities mentioned by the study patients included walking, general exercise, bicycle riding, exercise in water, swimming and dancing (Fig. 2). 
Various forms of activity were practised at a moderate level of intensity, at least once a week (Fig. 3). Women from the group engaging in different forms of activity (more than 5 types) had significantly higher scores for the "fighting spirit" variable in the Mini-MAC scale $(p=0.019)$.

Out of all types of physical activities mentioned in the survey, a significant relationship with selected quality-oflife parameters was identified for two: tourist trips and dancing. Study participants reporting regular trips (vs. patients not taking trips) gained statistically significant scores in the Mini-MAC study: fighting spirit ( $p<0.01$ ), positive orientation to the illness $(p=0.055)$ and constructive style of coping with the disease $(p<0.01)$ (Table 1$)$.

The patients who declared dancing to be one of their preferred forms of activity also scored higher in the SWLS $(p<0.05)$ and AIS $(p<0.05)$ scales (Table 2$)$.

The other forms of physical activity practised by the study subjects failed to show any correlation with different indicators of quality of life after breast cancer treatment.

\section{Discussion}

Breast cancer still requires radical management in many cases. Post-mastectomy women often experience reduced mobility and impaired muscle strength, as well as lymphoedema within the upper limb on the operated side. Postural defects may also develop in the course of time. What is more, physical complaints are often associated with psychological problems $[15,16]$. Consequently, it is vital to introduce rehabilitation treatment soon after surgery to enable patients to recover their independence and physical capability. In the light of available knowledge, taking up regular physical activity is also beneficial on the completion of treatment. Exercise produces favourable effects both in the physical and mental spheres (improved quality of life, active attitude towards the disease, elimination of emotional crisis) $[10,11,17,18]$. Research has shown that appropriately selected exercise reduces stress, or contributes to stress reduction, by helping eliminate anxiety, irritability and signs of depression. Physical exercise has been proven to increase

Table 1. Comparison of women confirming systematic participation in tourist trips in comparison to women without such activity

\begin{tabular}{|c|c|c|c|c|c|c|}
\hline \multirow[t]{3}{*}{ Scales } & \multicolumn{4}{|c|}{ Tourist trips } & \multicolumn{2}{|c|}{ Mann-Whitney test } \\
\hline & \multicolumn{2}{|c|}{ yes $(n=13)$} & \multicolumn{2}{|c|}{ no $(n=23)$} & \multirow[b]{2}{*}{$z$} & \multirow[b]{2}{*}{$p$} \\
\hline & mean & SD & mean & SD & & \\
\hline SWLS & 20.31 & 5.1 & 17.96 & 4.6 & -1.275 & 0.214 \\
\hline AIS & 29.38 & 7.7 & 28.3 & 7.6 & -0.610 & 0.558 \\
\hline BB & 11.31 & 2.4 & 13.39 & 4.2 & -1.495 & 0.140 \\
\hline $\mathrm{ZL}$ & 14.31 & 3.6 & 16.26 & 4.9 & -1.173 & 0.253 \\
\hline DW & 24.62 & 1.9 & 21.83 & 2.7 & -3.118 & 0.001 \\
\hline PP & 23.46 & 3.0 & 21.48 & 2.7 & -1.923 & 0.055 \\
\hline SK & 48.08 & 4.3 & 43.30 & 4.9 & -2.764 & 0.005 \\
\hline SD & 25.62 & 5.5 & 29.65 & 8.1 & -1.436 & 0.159 \\
\hline
\end{tabular}

SWLS - quality of life scale, AIS - acceptance of illness, ZL - Anxious Preoccupation, DW - Fighting Spirit, BB - Helplessness/Hopelessness, SK - constructive style $(D W+B B), S D$ - destructive style $(Z L+B B)$

Table 2. Comparison of women confirming systematic participation in dance activity in comparison to women without such activity

\begin{tabular}{|c|c|c|c|c|c|c|}
\hline \multirow[t]{3}{*}{ Scales } & \multicolumn{4}{|c|}{ Dance } & \multicolumn{2}{|c|}{ Mann-Whitney test } \\
\hline & \multicolumn{2}{|c|}{ yes $(n=10)$} & \multicolumn{2}{|c|}{ no $(n=26)$} & \multirow[b]{2}{*}{ z } & \multirow[b]{2}{*}{$p$} \\
\hline & mean & SD & mean & SD & & \\
\hline SWLS & 22.0 & 3.6 & 17.58 & 4.8 & -2.556 & 0.010 \\
\hline AIS & 32.50 & 8.0 & 27.23 & 7.0 & -2.335 & 0.019 \\
\hline BB & 11.00 & 1.9 & 13.27 & 4.1 & -1.656 & 0.101 \\
\hline $\mathrm{ZL}$ & 13.70 & 3.7 & 16.27 & 4.7 & -1.523 & 0.135 \\
\hline DW & 24.10 & 2.5 & 22.35 & 2.7 & -1.690 & 0.094 \\
\hline PP & 22.90 & 3.3 & 21.92 & 2.8 & -0.942 & 0.355 \\
\hline SK & 47.00 & 5.4 & 44.27 & 5.0 & -1.207 & 0.241 \\
\hline SD & 24.70 & 5.4 & 29.54 & 7.8 & -1.788 & 0.074 \\
\hline
\end{tabular}

SWLS - quality of life scale, AIS - acceptance of illness, ZL - Anxious Preoccupation, DW - Fighting Spirit, BB - Helplessness/Hopelessness, SK - constructive style $(D W+B B), S D$ - destructive style $(Z L+B B)$ 
the concentration of noradrenalin and serotonin in the brain. At elevated concentrations, the neurotransmitters are known to mitigate depressive symptoms. Endorphins released in increased amounts under the influence of physical exercise also cause mood elevation and reduced sensation of pain. In some cases they may even trigger off a feeling of bliss, or euphoria [19-22]. The present study indicates that surveyed patients appreciate the value of physical activity in the process of convalescence and rebuilding of physical and psychological function after cancer treatment. $94 \%$ of those surveyed claim that regular physical activity is necessary. Unfortunately, nearly $20 \%$ still fail to take up physical exercise, citing lack of time as the main reason. It should, however, be noted that members of the other subgroup (82\%) declare that they actually devote more time to physical exercise than they used to before the surgery. This attitude is a manifestation of the patients' active fight to regain health, which brings benefits both in the physical dimension (in the form of improved fitness and bodily efficiency) and in the psychological sphere.

The high degree of study women's awareness of the importance of post-cancer treatment activity is likely a result of their membership in the Amazons Club (81\% of women from the study group take part in Amazons Club sessions), where the topic is most certainly brought up quite frequently. The Club also functions as a support group in informative and organizational aspects and in the emotional sphere. Observing women who have been cured of cancer (i.e. survived more than 5 years without recurrence) gives confidence to other Amazons Club members, who can emulate their attitude, follow their example and be reassured that beating cancer is possible. In this way, anxiety and discomfort associated with the disease can be reduced. The need to attend meetings organized by the Amazons Club is very clearly visible among the study patients. As many as $91 \%$ of the study patients who have an opportunity to take part in the meetings because there is a local branch of the club in their town of residence are regular club visitors. Results of the present study demonstrate that participation in Amazons Club meetings is correlated with higher AIS scores $(p=0.01)$, i.e. better acceptance of the illness and limitations resulting from it. A comparison of mean MiniMAC scores obtained in the group of women belonging to the Amazons Club against results observed by other authors also confirms this thesis. Jurczyński reports that the mean score recorded among breast cancer patients for the constructive style of coping with the disease is $40.3( \pm 6.7)$ and for the destructive approach $35.8( \pm 9.4)$ [5]. Corresponding values recorded in our study among Amazons Club members were, respectively, $44.7( \pm 5.2)$ and $28.6( \pm 7.8)$. According to psychological studies, better prognosis (in terms of total survival period, absence of recurrence and generally better quality of life) is linked to active strategies of combating the neoplastic disease [6, 23-25]. What follows is that participation in the Amazons Club sessions should be regarded as a beneficial factor aiding the process of recovery after breast cancer therapy.

Members of the Amazons Club may take part in group physical activities (e.g. the study subjects practised gener- al physical exercise, swimming and water exercise). People undertaking the greatest number of physical recreation activities (more than five different types) tend to have the highest scores in the "fighting spirit" criterion. Scores recorded in the most active group of women in the present study deviate substantially from values reported by other authors. The mean "fighting spirit" score among women post-breast cancer therapy is $19.3( \pm 3.9)$ [5], while in the above group it was as high as $23.8( \pm 2.3)$. However, the available studies do not point to an unambiguous causal relationship: does the multitude of forms of activity have an impact on the style of coping with the disease? Or perhaps, vice versa, the patient's adopted method of coping (i.e. in this particular case the prevalence of the "fighting spirit" strategy) causes women to take up various forms of physical activity? Whichever the causal direction, physical activity definitely contributes to maintaining a good psychophysical condition. It is indisputable, though, that both of the factors referred to above (multiple forms of activity and prevalence of the "fighting spirit" strategy) are interconnected and their interaction is beneficial for the patients. The most immediate effect is keeping physically fit, while more remote benefits - considering the dominance of constructive strategies - include better prognosis understood as longer survival, lack of cancer recurrence and generally better quality of life [6, 23-25].

Importantly, the final section of the analysis of material collected in the present study leads to interesting and surprising conclusions. Tourist trips and dancing were found to have a special importance among all the activities mentioned by the study subjects. Trips satisfy needs related to the regeneration of physical and mental powers away from the place of permanent residence, which can be of significance for people staying permanently in the same environment, and stuck in their daily routine. Trip participants find that tourist endeavours help them disconnect from daily concerns and escape from mundane life, as well as creating an opportunity to socialize, which prevents feelings of loneliness. Furthermore, tourism offers a sense of independence and liberation. It creates the feeling of freedom and autonomy in making choices, satisfies the desire for new experiences, and supports the process of building up strength and improving health [26]. It turns out that tourism is not only implicated in the process of developing an active lifestyle, but also helps to overcome obstacles and eliminate the fear of physical effort, thus promoting an attitude based on courage and internal sense of power [27]. Results obtained in the Mini-MAC scale confirm that women reporting participation in activities of this type score very highly both in the "fighting spirit" and "positive orientation" strategies. The two strategies make up the so-called constructive style of coping with neoplastic disease which, in the group analysed, reaches the level of $48.1( \pm 4.4)$ against the mean score of ca. $40.3( \pm 6.7)$ reported in the literature [5].

Women declaring dance to be one of the forms of their regular physical activity scored markedly higher in the SWLS and AIS scales, which suggests higher satisfaction with life, as well as better acceptance of the disease and the limitations it causes. A number of authors have discussed the 
benefits of dancing, an activity which arouses spontaneity, eliminates tension through the release of accumulated emotions and increases body awareness [28-30]. Therefore, there is growing interest in choreotherapy as an adjunct to conventional rehabilitation in different disease types. Post-mastectomy women, who have lost their breast, are particularly vulnerable to having a distorted image of their body. Consequently, dancing can play a very important role in rebuilding their self-esteem, femininity and physical attractiveness. Results obtained in the present study substantiate this thesis. Study subjects attending dance classes achieved higher scores in the SWLS scale assessing the degree of life satisfaction $(22.0 \pm 3.6)$ than healthy women at a similar age not undertaking activities of this type $(18.4 \pm 5.3)$ [5]. AIS scores in this group are also very high $(32.5 \pm 8.0)$. Adopting the AIS to the specifically Polish settings, Jurczyński pointed out that the lowest scores are recorded in patients suffering from chronic pain $(18.4 \pm 7.0)$, while women with breast and womb cancers typically score $28.1 \pm 7.6$. Also, Guzińska [31] reports that due to cardiology rehabilitation in post-CABG patients the level of acceptance of disease rises from $22.8( \pm 5.5)$ to $27.1( \pm 6.7)$. Based on studies conducted in Poland among women after breast cancer surgery, an AIS score above 30 points is considered to signify good acceptance of the disease [1]. In the light of such data, dancing classes should be recognized as an excellent technique of improving the quality of life after breast cancer treatment both in terms of acceptance of the disease and its associated limitations.

Yet another aspect deserves to be mentioned in the summary. Both forms of physical activity which, as described above, are particularly strongly correlated with the quality of women's life after breast cancer treatment, share one common property. As opposed to exercise aimed at improving general fitness or water activities (swimming and exercises in water), they were not organized by the Amazons Club, so the women participated in those activities based on their own decision which required independent initiative. It needs to be noted, then, that aside from activities suggested by the Amazons Club the women also actively sought other types of physical recreation, possibly better suited to their needs and personal preferences. In this way, they also widened their circle of friends and acquaintances. The social aspect of physical activity also seems to play a part. Stepping out of the group of women associated in the Amazons Club offers a chance to meet people who have not undergone oncology treatment and, hence, to forget about the disease and distract themselves from problems brought by it.

\section{Conclusions}

Women regularly attending meetings of the Amazons Club accept their illness and disability to a greater extent than patients from the group not using support of this kind. Women after breast cancer treatment have a very high awareness of the role of physical activity in the process of recovery. The study subjects who engage in various forms of physical activity score highly in the "fighting spirit" strategy.

Out of various forms of physical recreation activities, a significant correlation was identified between two - tourist trips and dancing - and selected quality-of-life parameters. Women declaring tourist trips as one of their regular forms of physical activity exhibit a decidedly constructive style of coping with the disease (very high values in the "fighting spirit" and "positive orientation" strategies). In turn, women participating in dancing classes accept their disease better and are generally more satisfied with life in comparison with the other study subjects. Taking up physical activities outside the Amazons Club also appears beneficial to the patients.

\section{References}

1. Nowicki A, Ostrowska Ż. Akceptacja choroby przez chore po operacji raka piersi w trakcie leczenia uzupełniającego. Pol Merkuriusz Lek 2008; 24: 143, 403.

2. Tasiemski T, Kujawa M, Pokaczajło J. Jakość życia kobiet po mastektomii. Fizjoterapia 2009; 17: 48-58.

3. Surdyka D. Problemy medyczne i społeczne kobiet po mastektomii. In: Niepełnosprawność i rehabilitacja osób dorosłych jako problem medyczny i społeczny w Polsce. Karwat D (ed.). Wydawnictwo LIBER, Lublin 2002; 139-141

4. Andrzejewski W, Kassolik K, Ochrymowicz M, Pawłowska K. Ocena jakości życia kobiet po mastektomii zrzeszonych w Klubie Amazonek. Fizjoterapia Polska 2008; 1: 51-64.

5. Jurczyński Z. Narzędzia pomiaru w promocji i psychologii zdrowia. Pracownia Testów Psychologicznych PTP, Warszawa 2001.

6. Greer S, Morris T, Pettingale K. Psychological response to breast cancer diagnosis: effect on outcome. Lancet 1979; 785-7.

7. Malicka I, Pawłowska K. Aktywność ruchowa w prewencji pierwotnej i wtórnej raka piersi. Rehabilitacja Medyczna 2008; 12: 32-8.

8. Woźniewski M. Kultura fizyczna w życiu ludzi chorych na nowotwory złośliwe. Advances in Clinical and Experimental Medicine 2002; 11 supl. 1: 103-8.

9. Woźniewski M. Aktywność ruchowa u chorych na nowotwory złośliwe. In: Znaczenie aktywności ruchowej dla zdrowia. Murawska-Ciałowicz E, Zatoń M (eds.). AWF we Wrocławiu, Wrocław 2005.

10. Szczepańska-Gieracha J, Malicka I, Figuła M, Rymaszewska J, Woźniewski M. Wpływ ośmiotygodniowego treningu nordic walking na jakość życia kobiet po mastektomii. Onkol Pol 2010; 13: 90-5

11. Czerniak U, Demuth A. Związek poczucia jakości życia z podejmowaniem aktywności fizycznej kobiet po mastektomii, Medycyna Sportowa 2010; 2-3: 26, 98-105.

12. Diener E, Emmons RA, Larson RJ, Griffin S. The Satisfaction with Life Scale. Journal of Personality Assessment 1985; 49: 71-5.

13. Pavot W, Diener E. Review of The Satisfaction with Life Scale. Psychological Assessment 1993; 5: 164-72.

14. Watson M, Law M, Santos M, Greer S, Baruch J, Bliss J. The MiniMAC: further development of the Mental Adjustment to Cancer Scale. Journal of Psychological Oncology 1994; 12: 33-46.

15. Hack TF, Cohen L, Katz J, Robson LS, Goss P. Physical and psychological morbidity after axillary lymph node dissection for breast cancer. J Clin Oncol 1999; 17: 143-9.

16. Lueboonthavatchai P. Prevalence and psychosocial factors of anxiety and depression in breast cancer patients. J Med Assoc Thai 2007; 90: 2164-74

17. Pinto B, Trunzo J, Reiss P, Shiu S-Y. Exercise participation after diagnosis of breast cancer: trends and effects on mood and quality of life. Psychooncology 2002; 11: 389-400.

18. Valent M, Porzio G, Aielli F, et al. Physical Exercise and Quality of life in breast cancer survivors. Int J Med Sci 2008; 5: 24-8.

19. Burnham TR, Wilcox A. Effects of exercise on physiological and psychological variables in cancer survivors Med Sci Sports Exerc 2002; 34: 1863-7.

20. Harber VJ, Sutton JR Endorphins and exercise. Sports Med 1984; Sports Med 1984; 1: 154-71.

21. Schwarz L, Kindermann W. Changes in beta-endorphin levels in response to aerobic and anaerobic exercise. Sports Med 1992; 13: 25-36. 
22. Bender T, Nagy G, Barna I, Tefner I, Kádas E, Géher P. The effect of physical therapy on beta-endorphin levels. Eur J Appl Physiol 2007; 100: 371-82.

23. Pettingale KW. Doping and cancer prognosis. J Psychosom Res 1984; 28: 363-4.

24. Pettingale KW, Morris T, Greer S, Haybittle JL. Mental attitudes to cancer: an additional prognostic factor. Lancet 1985; 30: 750.

25. Morris T, Pettingale KW, Haybittle JL. Psychological response to cancer diagnosis and disease outcome in patient with breast cancer and lymphoma. Psycho-Oncology 1992; 1: 105-14.

26. Zamłyńska K. Turystyka i rekreacja a promocja zdrowia rodziny. Roczniki Naukowe AWF w Poznaniu 2005; 54.

27. Przecławski K. Turystyka a człowiek i społeczeństwo. Instytut Wydawniczy Związków Zawodowych, Warszawa 1984.

28. Sandel SL, Judge JO, Landry N, Faria L, Ouellette R, Majczak M. Dance and movement program improves quality-of-life measures in breast cancer survivors. Cancer Nurs 2005; 28: 301-9.

29. Cohen SO, Walco GA. Dance/Movement therapy for children and adolescents with cancer. Cancer Pract 1999; 7: 34-42.

30. Molinaro J, Kleinfeld M, Lebed S Physical therapy and dance in the surgical management of breast cancer. A clinical report. Phys Ther 1986; 66: 967-9.

31. Guzińska K, Kupc A, Borys B. Zasoby odporności na stres w procesie zdrowienia u pacjentów z chorobą niedokrwienną serca. Psychiatria 2007; 4: 144-52

\section{Address for correspondence}

Iwona Malicka MD, PhD

Wydział Fizjoterapii

AWF Wrocław

al. I.J. Paderewskiego 35

51-612 Wrocław, Poland

tel. +48713473519

$\mathrm{fax}+48713473081$

e-mail: iwona.malicka@awf.wroc.pl 